\title{
ASSOCIATION OF ACTN3 R577X AND ACE I/D POLYMORPHISMS IN BRAZILIANS WRESTLERS
}

\author{
ASSOCIAÇÃO DOS POLIMORFISMOS ACTN3 R577X E ACE I/D EM LUTADORES BRASILEIROS \\ ASOCIACIÓN DE LOS POLIMORFISMOS ACTN3 R577X Y ACE I/D EN LUCHADORES BRASILEÑOS
}

Original Article

ARTIGO ORIGINAL

Artículo Original

\author{
Marcelo Romanovitch Ribas 3 \\ (Physical Education Professional) \\ Zair Candido Oliveira Netto \\ (Physical Education Professional) \\ Fabiano Salgueirosa' \\ (Physical Education Professional) \\ Priscila Fernandes ${ }^{2}$ \\ (Physiotherapist) \\ Oslei de Matos \\ (Physical Education Professional) \\ Julio Cesar Bassan 1,2,3 \\ (Physical Education Professional)
}

1. Universidade Tecnológica Federal do Paraná (UTFPR), Programa de Pós-Graduação em Engenharia Biomédica (PPGEB), Curitiba, PR, Brazil. 2. Universidade Tecnológica Federal do Paraná (UTFPR), Programa de Pós-Graduação em Educação Física (PPGEF), Curitiba, PR, Brazil. 3. Universidade Tecnológica Federal do Paraná (UTFPR), Programa De Pós-Graduação em Engenharia Elétrica e Informática Industrial (CPGEI), Curitiba, PR, Brazil.

\section{Correspondence:}

Universidade Federal Tecnológica do Paraná. ITech - Inovação em Biotecnologia e Saúde. Av. Sete de Setembro, 3165, Rebouças, Curitiba, PR, Brazil. 80230-901. mromanovitch@yahoo.com.br

\begin{abstract}
Introduction: By associating genetics and sport, it is possible to identify subjects with greater capacity to adapt to training, and lower chances of injury. Objective: The investigation evaluated the genotypic and allelic distribution of ACTN3 R577X and ACE I/D polymorphisms in Brazilian high-performance athletes in wrestling and percussion combat sports. Methods: The study included 37 male athletes ranked from first to third place in world scenarios, divided into two groups: wrestling (23 wrestlers, being 11 of Judo, 4 of Greco-Roman style, 8 of Brazilian Jiu Jitsu, with mean age of $27.3 \pm 6.9$ years) and percussion combat sports (14 athletes with

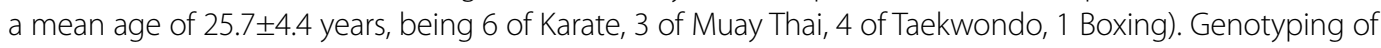
ACTN3 and ACE I/D polymorphisms was performed by polymerase chain reaction (PCR) from the genomic DNA. Genotypic and allelic distributions were compared with control populations and athletes by Chi-square test and Fisher's exact test; all analyzes considered $p \leq 0.05$. Results: The genotypic distributions and allelic frequencies of $A C T N 3 R R=46 \%, R X=38 \%$ and $X X=16 \% ; R=65 \%$ and $X=35 \%$, and $A C E I / D$ DD $=47.7 \%, I D=34.3 \%$ and $I I=20 \% ; D=62.9 \%$ and $I=37.1 \%$ did not differ from the control population; however, when compared with wrestling athletes a significant difference was observed. Conclusion: These results suggest an association of ACTN3 R577X and ACE I/D genes with Brazilian high-performance wrestling athletes.
\end{abstract}

Keywords: athletes; actinin/genetics; peptidyl-dipeptidase A; ethnic groups/genetics.

\section{RESUMO}

Introdução: Ao associar genética e esporte, existe a possibilidade de identificar sujeitos com maior capacidade de adaptação ao treinamento com menores chances de lesões. Objetivo: A investigação avaliou a distribuição genotípica e alélica dos polimorfismos ACTN3 R577X e ACEI/D em lutadores de domínio e percussão de alto rendimento brasileiros. Métodos: Participaram do estudo 37 atletas do sexo masculino, colocados de primeiro a terceiro lugar nos cenários mundiais, divididos em dois grupos: domínio (23 lutadores sendo 11 de judô, 4 de luta greco-romana, 8dejiu-jitsu brasileiro; a média de idade foi $27,3 \pm 6,9$ anos) e percussão (14 atletas com média de idade de $25,7 \pm 4,4$ anos sendo 6 de caratê, 3 de muay thai, 4 de taekwondo, 1 de boxe). A genotipagem dos polimorfismos do ACTN3 e ACE I/D foi realizada por reação em cadeia da polimerase (PCR) a partir do DNA genômico. As distribuições genotípicas e alélicas foram comparadas com populações controle e de atletas pelos testes do qui-quadrado e exato de Fisher; todas as análises consideraram $p \leq 0,05$. Resultados: As distribuições genotípicas e frequências alélicas do $A C T N 3 R R=46 \%, R X=38 \%$ eXX $=16 \% ; R=65 \%$ eX $X 35 \%$ e $A C E I / D D D=47,7 \%$, ID=34,3\% e $\|=20 \% ; D=62,9 \%$ e I=37,1\% não diferiram da população controle, porém, quando comparadas com atletas de luta, constatou-se diferença significativa. Conclusão: Esses resultados sugerem uma associação dos genes ACTN3 R577X e ACE I/D aos lutadores de domínio de alto rendimento brasileiros.

Descritores: atletas; actinina/genética; peptidil dipeptidase A; grupos étnicos/genética.

\section{RESUMEN}

Introducción: Al asociar genética y deporte, existe la posibilidad de identificar sujetos con mayor capacidad de adaptación a los entrenamientos con menores posibilidades de lesión. Objetivo: La investigación evaluó la distribución genotípica y alélica de los polimorfismos ACTN3 R577X y ACE I/D en luchadores brasileños de alto rendimiento de técnicas de agarrey golpeo. Métodos: Participaron en el estudio 37 atletas del sexo masculino, colocados de primer a tercer lugar en escenarios mundiales, divididos en dos grupos: agarre (23 luchadores, siendo 11 de judo, 4 de lucha grecorromana y 8 de jiu-jitsu; el

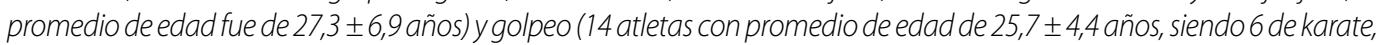
3 de muay-thai, 4 de taekwondo y 1 de boxeo). El genotipado de los polimorfismos de ACTN3 y ACE I/D se llevó a cabo por reacción en caden a de la polimerasa (PCR) a partirde ADN genómico. Las distribuciones genotípicas y alélicas fueron comparadas con poblaciones controly atletas por las pruebas del chi-cuadrado y exacta de Fisher; todos los análisis consideraron $p$ $\leq 0,05$. Resultados: Las distribuciones de los genotipos y frecuencias alélicas de $A C T N 3 R R=46 \%, R X=38 \%$ y $X X=16 \% ; R=65 \%$ y $X=35 \%$ y $A C E I / D D D=47,7 \%, I D=34,3 \%$ e $\|=20 \% ; D=62,9 \%$ e $I=37,1 \%$ no difirieron de la población control, sin embargo, cuando comparadas con los atletas de lucha, se constató diferencia significativa. Conclusión: Estos resultados sugieren una asociación de los genes ACTN3 R577X y ACE I/D a los luchadores brasileños de alto rendimiento de técnicas de agarre.

Descriptores: atletas; actinina/genética; peptidil-dipeptidasa A; grupos étnicos/genética. 


\section{INTRODUCTION}

Although the triad training, proper nutrition and psychological factors can contribute to the athletic success ${ }^{1}$, it is observed over the years that such factors are not enough to characterize a phenotype of status of physical performance in humans ${ }^{2}$. The sports of combat can be divided into grappling (judo, Brazilian Jiu-Jitsu, Greco-Roman wrestling) and percussion (as Karate, Taekwondo, Muay Thay, boxing, etc) ${ }^{3-7}$. But when the dynamics of these modalities are analyzed, the grappling fights present these characteristics of effort: pause of $2: 1$ or $3: 1^{3-5}$ and the fights of percussion with relations of effort: pause of $1: 6$ to $1: 9^{6,7}$. It is observed that they are formed by short and intermittent stimulus, being the time of stimulus superior to the time of the pause ${ }^{8}$.

Therefore, athletes of grappling and percussion fights need to have an efficient glycolytic metabolism for energy transfer. This because many times these fights calls for movements of high power to perform muscular actions ${ }^{9}$, and they also need an aerobic capacity adequate to sustain the performance during the fighting ${ }^{10}$. Thus, it is suggested that the ability of some wrestlers to protrude in their specific sports of combat can be directly related to genetic predisposition ${ }^{11}$. Studies carried out in the post-genome era, about genetics and physical qualities have shown the reliability of genetic markers for molecular prognosis of human physical performance ${ }^{12}$. There is growing evidence that there are strong genetic influences on athletic performance and for an evolutionary change in performance characteristics for activities of speed, strength and resistance ${ }^{13}$. This phenomenon can be illustrated by the variation R577X in ACTN3 gene, encoding the protein a-actinina-3, a protein that is necessary to perform explosive muscle actions. This protein is almost exclusively expressed in muscle fibers of fast contraction ${ }^{14}$ and the I/D polymorphism of the ACE in which the I allele is reported as the most frequent in endurance athletes, while the $D$ allele is present in athletes of strength and muscle explosion ${ }^{15}$. So, the objective of this research was to evaluate the genotypic and allele distribution of ACTN3 R577X and ACE I/D polymorphisms in Brazilian grappling and percussion wrestlers of high performance.

\section{METHODS}

The population of this study consisted of 37 Brazilian athletes of high performance, with a prominent position on the world scenario in their respective modalities. The selection criterion was athletes with the first to third colocation. This restricts significantly our study group. This study group was divided into two groups: grappling (23 male athletes of high performance being 11 Judo athletes, 4 of Greco Roman Wrestling and 8 Brazilian Jiu-Jitsu athletes, all of them with mean age $27.3 \pm 6.9$ years) and percussion (14 male athletes with an average age of $25.7 \pm$ 4.4 years, being 6 Karate athletes, 3 Muay Thai wrestlers, 4 Taekwondo athletes and 1 of Boxing).

Wrestlers and high-performance percussion athletes with national or international results aged between 18 and 44 years were included in this experiment. The following athletes were excluded: the ones that expressed their intention not to participate in the study; blood samples that for technical reasons were not possible to extract the DNA and amplify it. For this purpose 37 athletes were tested for ACTN3 gene and 35 subjects were tested for ACE gene. The loss of this sample for the ACE gene happened because of non-amplification of two samples. All participants were informed about the research procedures, requirements, benefits and risks before providing written informed consent. The study was approved by the Ethics in Research Committee, of the Faculty Don Bosco PR / BR on the opinion $n^{\circ} 489.086$.

For the analysis of genotypes for polymorphisms in genes ACTN3 R577X and ACE I/D, $10 \mathrm{ml}$ of blood were collected from forearm veins of all athletes. The genomic locus containing the polymorphic site was amplified using the PCR-RFLP (polymerase chain reaction associated with the restriction fragment length polymorphism). The exon 15 of the ACTN3 gene, where the polymorphism was amplified using the following primers: forward 5'-CTGTTGCCTGTGGTAAGTGGG -3' and reverse 5'-TGGTCACAGTATGCAGGAGGG-3', anchored in the intronic sequence upstream ${ }^{14}$.

The reaction system had a total volume of $25 \mathrm{uL}$, comprising $1 \mathrm{x}$ Taq Buffer, $1.5 \mathrm{mM} \mathrm{MgCl}_{2}, 0.2 \mathrm{mM}$ dNTPs, $1.0 \mathrm{M}$ of each primer, 1 unit of Taq DNA polymerase and 100 ng genomic DNA as template. The amplification program consisted of the following steps: $95^{\circ} \mathrm{C}$ for $5 \mathrm{mi}$ nutes initial denaturation and enzyme release, followed by 30 cycles of denaturation at $94^{\circ} \mathrm{C}$ for 30 seconds, annealing at $58^{\circ} \mathrm{C}$ for 30 seconds, final extension at $72^{\circ} \mathrm{C}$ for 30 seconds. On completion of the 30 cycles, there was a 5 minute final extension at $72^{\circ} \mathrm{C}$. After amplification, $10 \mu \mathrm{L}$ of the PCR product were digested by 10 units of Ddel enzyme for 4 hours in a water bath at $37^{\circ} \mathrm{C}$. The $\mathrm{R}$ or $\mathrm{X}$ alleles (codons TGA and CGA) were distinguished by the presence (577X) or absence (577R) of restriction enzyme Ddel site of the (5-TNA $\downarrow$ C G-3) ${ }^{14}$. The restriction fragments were separated by agarose gel electrophoresis at 3\%, and revealed with ethidium bromide at $5 \mathrm{ug} / \mathrm{ml}$. The ACTN3 577R allele generates fragments of 205 and 86 base pairs (bp), while the ACTN3 allele 577X generates fragments of 108.97 and $86 \mathrm{bp}^{13}$.

The I/D polymorphism of the ACE gene is the absence (deletion or D allele) or presence (insertion and I allele) of 287 base pairs in intron 16. Thus, the 16 intron was amplified using the following primers: (forward 5 'CTGGAGAGCCACTCCCATCC TाCT 3 and reverse 5 ' GATGTGGCCATCACATTCGTCAGAT 3) ${ }^{16}$. The reaction system had a total volume of $25 \mathrm{uL}$, being composed of 1XTaq Buffer, $3.0 \mathrm{mM} \mathrm{MgCl2,0.2} \mathrm{mM} \mathrm{dNTPs,} 1.0 \mathrm{M}$ of each primer, 5\% dimethyl sulfoxide (DMSO), 1 Taq DNA polymerase and unit 100 ng of genomic DNA as template. The amplification program consisted of the following steps: $95^{\circ} \mathrm{C}$ for 5 minutes initial denaturation and enzyme release, followed by 30 cycles of denaturation at $94^{\circ} \mathrm{C}$ for 30 seconds, annealing at $57^{\circ} \mathrm{C}$ for 1 minute, extension at $72^{\circ} \mathrm{C}$ for 1 minute. After the completion of the 30 cycles, there was a 5 minute final extension at $72^{\circ} \mathrm{C}$. The fragments were separated by agarose gel electrophoresis on $3 \%$ and revealed with ethidium bromide at $5 \mu \mathrm{g} / \mathrm{ml}$. The D allele of the ACE gene produces a fragment of 191 base pairs, while the I allele generates a fragment of 478 base pairs, containing the insert of $287 \mathrm{bp}$.

According to the literature, the erroneous classification of heterozygous D/I as being homozygotes D/D may occur due to preferential amplification of the $D$ allele and to the inefficient amplification the I allele ${ }^{17}$. Therefore, to increase the specificity of the genotyping, the samples that presented D/D genotype were re-evaluated by a new PCR using a specific primer for the incorporation: forward 5'TTGAGACGGAGTCTCGCTC 3 , reverse 5 GATGTGGCCATCACATTCGTCAGAT3 and the reverse primer 5' - 3'. Additional reactions (specific to insert) had the same concentrations of the first PCR reagents. The amplification program was: $95^{\circ} \mathrm{C}$ for 5 minutes initial denaturation and enzyme release, followed by 35 cycles of denaturation at $94^{\circ} \mathrm{C}$ for 30 seconds, annealing at $56^{\circ} \mathrm{C}$ for 1 minute, extension at $72^{\circ} \mathrm{C}$ for 1 minute. On completion of the 35 cycles, there was a 5 minute final extension at $72^{\circ} \mathrm{C}^{17}$.

The results were visualized after electrophoresis on agarose gel and stained with $3 \%$ ethidium bromide at $5 \mu \mathrm{g} / \mathrm{ml}$. The appearance of a 408 base pair band is indicative of the presence of I allele, which means that, the samples previously genotyped as D/D are now classified as I/D. Samples classified as I/D and I/I in the first reaction were used as positive controls for the specific reaction for insertion.

\section{Statistical analysis}

In order to compare the frequencies of genotypes with other published studies, the chi-square test of Pearson was conducted. When the number of incidence of some genotype was less than 5, the Fisher's exact test was made. The associations between the frequencies of the alleles were verified by $2 \times 2$ contingency tables analyzed by Chi-square test with Yates correction. The genotype distribution of the ACTN3 
gene and ACE I/D were made by the Hardy-Weinberg equilibrium test. For this purpose we used the BioState 5.02007 software, with a significance level of $p=0.05$

\section{RESULTS}

The genotypic frequency of ACTN3 R577X and ACE I/D polymorphisms between all of the wrestlers and the percussion group followed the Hardy-Weinberg equilibrim (ACTN3: $x^{2}=1.07$ and $0.83, p=0.30$ and 0.36, ACE: $x^{2}=2.47$ and $0.03, p=0.11$ and 0.85$)$, but this did not occur with the domain group ( $A C T N 3$ : $x 2=4.15, p=0.04 ; C E A: x^{2}=4.87, p=0.02$ ). Genotype distribution for ACTN3 R577X polymorphism is presented in Table 1. There was no significant difference in genotypic distribution for the ACTN3 R577X polymorphism considering all wrestlers and when these were separate in grappling and percussion groups and the control Coelho ${ }^{18} \mathrm{p} \geq 0.05$. However, when comparing the grappling group of this research with the study of Kikuchi et al. ${ }^{19}$ and Rodriguez-Romo et al. ${ }^{20}$ it was found a significant difference $p=0.0483$ and $p=0.0066$ respectively.

The allele frequency of ACTN3 R577X polymorphism is presented in Table 2. There was no significant difference in allele frequency for the ACTN3 R577X polymorphism among all wrestlers and when they were separated into groups of wrestlers and the control Coelho ${ }^{18} p \geq 0.05$. However, when all the wrestlers and the grappling group of the present study are compared with Rodriguez-Romo et al. ${ }^{20}$ results, a significant difference of $p=0.0225$ and $p=0.0596$ was found respectively.

The genotype distribution for the ACE I/D polymorphism is presented in Table 3. There was no significant difference in genotype distribution for the ACE I/D polymorphism among all wrestlers and when these were separated in grappling and percussion groups and Meira-Lima control et al. ${ }^{21}$ $p \geq 0.05$. However, when all wrestlers and grappling groups and percussion of this research are compared with the study of Cieszczyk et al. ${ }^{22}$ a significant difference $p=0.0032, p=0.0011$ and $p=0.0581$ was found respectively.

The allele frequency for the ACE I/D polymorphism is presented in Table 4. There was no significant difference in allele frequency for the ACE I/D polymorphism among all wrestlers and when they were separated into groups of wrestlers and Meira-Lima et al. ${ }^{21}$ control $p \geq 0.05$. However, when comparing all the wrestlers and the grappling group of this research, with research of Cieszczyk et al. ${ }^{22}$ it was found a significant difference of $p=0.0085$ and $p=0.0143$ respectively.

Table 1. Frequency distribution of ACTN3 R577X polymorphisms.

\begin{tabular}{c|c|c|c|c|c|c}
\hline & \multicolumn{7}{|c|}{ Genotypic distribution $\mathbf{n}(\%)$} & & & \\
\hline Subjects (n) & $\mathbf{R R}$ & $\mathbf{R X}$ & $\mathbf{X X}$ & $\mathbf{p}$ value & $\mathbf{p}$ value & $\mathbf{p}$ value \\
\hline $\begin{array}{c}\text { All the } \\
\text { wrestlers (37) }\end{array}$ & $17(46)$ & $14(38)$ & $6(16)$ & 0.6938 & 0.1207 & $0.0151^{*}$ \\
\hline Grappling (23) & $12(52.2)$ & $6(26.1)$ & $5(21.7)$ & 0.2086 & $0.0483^{*}$ & $0.0066^{*}$ \\
\hline Percussion (14) & $5(37.7)$ & $8(57.1)$ & $1(7.2)$ & 0.6643 & 0.4358 & 0.2701 \\
\hline $\begin{array}{c}\text { Coelho }{ }^{18} \text { Con- } \\
\text { trol }^{-19}\end{array}$ & $40(40)$ & $46(46)$ & $14(14)$ & & & \\
\hline Kikuchi et al. ${ }^{19}$ & $38(28)$ & $68(50)$ & $29(22)$ & & & \\
\hline $\begin{array}{c}\text { Rodriguez- } \\
\text {-Romo et al. }{ }^{20}\end{array}$ & $23(22.3)$ & $60(54.6)$ & $25(23.1)$ & & & \\
\hline
\end{tabular}

Table 2. Allele frequency of ACTN3 R577X polymorphisms.

\begin{tabular}{|c|c|c|c|c|c|}
\hline \multirow[b]{2}{*}{ Subjects (n) } & \multicolumn{2}{|c|}{ Allele frequency $n(\%)$} & \multirow[b]{2}{*}{$\mathrm{p}$-value } & \multirow[b]{2}{*}{$\mathrm{p}$-value } & \multirow[b]{2}{*}{$\mathrm{p}$-value } \\
\hline & $\mathbf{R}$ & $x$ & & & \\
\hline All the wrestlers (37) & $48(65)$ & $26(35)$ & 0.8860 & 0.1015 & $0.0225^{*}$ \\
\hline Grappling (23) & 30(65.2) & 16(34.8) & 0.9110 & 0.1811 & $0.0596^{*}$ \\
\hline Percussion (14) & 18(64.2) & 10(37.7) & 0.9386 & 0.3638 & 0.1737 \\
\hline Coelho ${ }^{18}$ Control & $126(63)$ & 74(37) & & & \\
\hline Kikuchi et al. ${ }^{19}$ & 144(53) & $126(47)$ & & & \\
\hline Rodriguez-Romo et al. ${ }^{20}$ & 104(49.6) & $110(50.4)$ & & & \\
\hline
\end{tabular}

Table 3. Genotypic Distribution of ACE I/D polymorphism.

\begin{tabular}{|c|c|c|c|c|c|c|}
\hline \multirow[b]{2}{*}{ Sujeitos (n) } & \multicolumn{3}{|c|}{ Genotypic distribution $\mathbf{n}(\%)$} & \multirow[b]{2}{*}{$p$-value } & \multirow[b]{2}{*}{$p$-value } & \multirow[b]{2}{*}{$p$-value } \\
\hline & $\mathrm{DD}$ & ID & II & & & \\
\hline $\begin{array}{c}\text { All the } \\
\text { wrestlers (35) }\end{array}$ & $16(45.7)$ & $12(34.3)$ & $7(20)$ & 0.2240 & 0.8191 & $0.0032^{*}$ \\
\hline Grappling (21) & $11(52.4)$ & $5(23.8)$ & $5(23.8)$ & 0.0805 & 0.8774 & $0.0011^{*}$ \\
\hline Percussion (14) & $5(37.7)$ & $7(57.1)$ & $2(7.2)$ & 0.8728 & 0.2658 & $0.0581^{*}$ \\
\hline $\begin{array}{c}\text { Meira-Lima } \\
\text { et al. } .^{21} \text { (control) }\end{array}$ & 104(32.2) & $155(48)$ & 64(19.8) & & & \\
\hline Kikuchi et al. ${ }^{19}$ & $68(50.3)$ & $39(28.9)$ & $28(20.8)$ & & & \\
\hline Cieszczyk et al. ${ }^{22}$ & $2(7.1)$ & $18(64.3)$ & $8(28.6)$ & & & \\
\hline
\end{tabular}

Table 4. Allele frequency of ACE I/D polymorphism

\begin{tabular}{c|c|c|c|c|c}
\hline & \multicolumn{2}{|c|}{ Allele frequency $\mathbf{n}(\%)$} & & & \\
\hline Subjects (n) & $\mathbf{D}$ & $\mathbf{I}$ & $\mathbf{p}$ valor & p valor & p valor \\
\hline All the wrestlers (37) & $44(62.9)$ & $26(37.1)$ & 0.2849 & 0.8691 & $0.0085^{*}$ \\
\hline Grappling (23) & $27(64.3)$ & $15(35.7)$ & 0.3050 & 0.9468 & $0.0143^{*}$ \\
\hline Percussion (14) & $17(64.2)$ & $11(37.7)$ & 0.6366 & 0.8227 & 0.0634 \\
\hline $\begin{array}{c}\text { Meira-Lima et al. }{ }^{21} \\
\text { Control }\end{array}$ & $363(63)$ & $283(37)$ & & & \\
\hline Kikuchi et al. ${ }^{19}$ & $175(53)$ & $95(47)$ & & & \\
\hline Cieszczyk et al..$^{22}$ & $22(49.6)$ & $34(50.4)$ & & & \\
\hline
\end{tabular}

\section{DISCUSSION}

This study is the first to investigate the genotypic and allele frequency of ACTN3 and ACE genes in high-performance Brazilian grappling and percussion wrestlers. It was observed (in Table 1), a higher frequency of the RR genotype, $52.2 \%$, followed by RX $26.1 \%$ and XX $21.7 \%$ in the grappling wrestlers of this research. When the same sample was compared to the study made by Kikuchi et al. ${ }^{19}$ which evaluated Judo Japanese athletes and Rodriguez-Romo et al. ${ }^{20}$, who studied Spanish Judo athletes, there was a significant difference between the studies. It is worth mentioning that the RR and RX genotype are related to a better performance in activities requiring speed, muscle strength, hypertrophy and the athletes who have a predominance of type IIx fibers ${ }^{13,14,23-25}$.

In the study made by Kikuchi et al. ${ }^{19}$, when the genotyping of 135 Japanese Judo athletes was performed, the authors concluded that judo athletes with an international level had a higher correlation with the RR and RX genotype, what demonstrates a genetic predisposition. This genetic predisposition corroborates the present research. However Rodriguez-Romo et al. ${ }^{20}$ performed the genotyping of 108 athletes and did not found a positive association with the R577X polymorphism and the status of being an elite athlete in judo, at least in the Spanish population. For the same authors, at least according to the ACTN3 R577X polymorphism, the elite judo athlete's genotype looks like the mixed type of athletes and non-athletes with force and muscle power characteristics, demonstrating that sports performance is polygenic.

In the genotype distribution of $R$ and $X$ alleles (Table 2), the present study found a distribution of $65 \%$ for the $R$ allele and of $35 \%$ for the $X$ allele for all wrestlers who were included in the study. Several works in different modalities, Greeks teenagers and 40 meter race Moran et al. ${ }^{26}$ finnish athletes of strength and power Niemi and Majamaa ${ }^{23}$, sprinters and Spanish road cyclists Fiuza-Luces et al. ${ }^{27}$ demonstrated an association between allele R with strength and power sports, and X allele with endurance sports. But the data of grappling and percussion wrestlers are somewhat scarce and controversial, Kikuchi et al. ${ }^{19}$ found in Japanese athletes an allele distribution of 53\% for the R allele and $47 \%$ for allele X, values which corroborate this research. However, Rodriguez-Romo et al. ${ }^{20}$ investigating Spanish wrestlers had a distribution for the R allele of $49.9 \%$ and $50.4 \%$ of the $X$. These findings discard a great influence of performance for this polymorphism. These findings suggest that an individual may possess innate characteristics that benefit him in modalities which have specific characteristics, this may be a result of genetic variation maintained by natural selection, for example, the $577 X$ allele of the ACTN3 gene ${ }^{28}$. 
Regarding the genotype distribution of ACE gene (Table 3), a higher frequency of the DD genotype was observed: $52.4 \%$ followed by $23.8 \%$ for ID and II in the grappling group of the present research. These values present a significantly different between genotype distributions compared to Cieszczyk et al. ${ }^{22}$ who studied Polish and Lithuanian judo athletes. Recent studies have shown that the I allele is more frequent in endurance athletes, while the D allele is in athletes with strength and muscle explosion ${ }^{29}$. Studying Japanese elite athletes, Kikuchi et al. ${ }^{19}$ reported values of $50.3 \%$, $28.9 \%$ and $20.8 \%$ for the DD, ID and II genotypes respectively, showing an association between the wrestlers of this study and the D allele, a fact that has to reinforces the present research. However, the study of Cieszczyk et al. ${ }^{22}$ with 28 elite wrestlers of Poland and Lithuania, the authors found a genotype distribution of $7.1 \%, 64.3 \%$ and $28.6 \%$ for DD, ID and II respectively, values that are different from those from this research.

About the allele distribution of the ACE I/D gene (Table 4), the present investigation found values for the D allele of $62.9 \%, 64.3 \%$ and $64.2 \%$ and $37.1 \%$ of the $1,35,7 \%$ and $37.7 \%$ for all wrestlers, grappling and percussion groups, respectively. When these data were compared with the research of Cieszczyk et al. ${ }^{22}$ a significant difference was found, the authors reported conflicting data with the present investigation, where the distribution of the D allele was $39.3 \%$ and the I allele of $60.7 \%$ to the authors, the highest incidence of genotype I/II is due to the length of a fight that can reach $5 \mathrm{~min}$. In a population of Japanese elite wrestlers, Kikuchi et al. ${ }^{19}$ found an allele distribution of $63 \%$ for $D$ and $37.7 \%$ for the I allele, values close to those observed in the present study, demonstrating a genetic predisposition to the studied sample.

A possible hypothesis for the favoring of this sample for the studied genes and their alleles linked to the strength and speed, and the other studies, could reside in the sustaining of epigenetics, which considers that the practice of physical exercise on a regular basis and searches the over compensation, answer this influenced by genes and life experiences. Therefore the changes not stable, but communicable, interact during a biological response, and that the interaction between genes and stimuli can change in much the expected results ${ }^{30}$.

\section{CONCLUSIONS}

In conclusion the results presented here suggest a genetic predisposition for Brazilian elite fighters which were included in this research. It was verified that the genotypic distribution of Brazilian fighters of this research, were favorable to activities of strength and power, because they were larger than in the control population. ACTN3 - RR (46\% vs $40 \%$ ) and ACE - DD (45.7\% vs $32.2 \%)$. The current research also suggests that the more predisposed to grappling and percussion fights, are individuals with the distribution of alleles of genes ACTN3 and ACE more significant regarding to the strength and muscle power. This because these fights are characterized by short and intermittent stimuli, being the time of stimulus superior than that of the pause. However, further studies should be performed to clarify the possible role of ACTN3, ACE and other polymorphisms to determine the athletic performance the elite fighters. The results can be used in the identification and selection of young athletes of fighters that have a greater genetic potential favorable to succeed in sports to combat of grappling and percussion in the design of customized training based on genotype.

All authors declare no potential conflict of interest related to this article.

AUTHOR CONTRIBUTIONS: Each author made significant individual contributions to this manuscript. MRR (0000-0002-2979-7282)*, ZCON (0000-0001-8579-9664)*, FS $(0000-0002-6555-7227)^{*}$ and PF $(0000-0001-9877-1257)^{*}$ contributed to the collection of data and writing of the manuscript. FS (0000-0002-6555-7227)*, OM (00000002-5422-9623) and JCB (0000-0001-5729-9582)* followed the data collections, guided the construction of the study, and assisted in the statistical analysis and revision. All authors contributed to the intellectual concept of the study. ${ }^{*}$ ORCID (Open Researcher and Contributor ID).

\section{REFERENCES}

1. Jeukendrup A, Cronin L. Nutrition and elite young athletes. Med Sport Sci. 2011;56:47-58

2. Dias RG, Pereira AC, Negrão CE, Krieger JE. Genetic polymorphisms determining of the physical performance in elite athletes. Rev Bras Med Esporte. 2007;13(3):209-16.

3. Del Vecchio FB, Bianchi S, Hirata SM, Chacon-Mikahili MPT. Análise morfo-funcional de praticantes de Brazilian jiu-jistsu e estudo da temporalidade e da quantificação das ações motoras na modalidade. Movimento e Percepção. 2007;7(10):263-81.

4. Marcon G, Franchini E, Jardim JR, Barros NTL. Structural analysis of action and time in sports: judo. J Quant Anal Sports. 2010,6(4):1-15.

5. Nilsson J, Csergö S, Gullstrand L, Tveit P, Refsnes PE. Work-time profile, blood lactate concentration and rating of perceived exertion in the 1998 Greco-Roman Wrestling World Championship. J Sports Sci. 2002;20(11):939-45.

6. lide K, Imamura H, Yoshimura Y, Yamashita A, Miyahara K, Miyamoto N, et al. Physiological responses of simulated karate sparring matches in young men and boys. J Strength Cond Res. 2008;22(3):839-44.

7. Matsushigue KA, Hartmann K, Franchini E. Taekwondo: Physiological responses and match analysis. J Strength Cond Res. 2009;23(4):1112-7.

8. Olívio Júnior JA, Borin PJ, Pasqualoto BB, Braz TV. Modelação Competitiva dos Aspectos Temporais em Lutas de Judô na Classe Juvenil. Saúde Rev. 2009;11(28/29):17-26.

9. Franchini E, Takito YM, Lima PRJ, Haddad S, Kiss DPAM, Regazzini M, et al. Physiological characteristics in laboratorial tests and blood lactate response in three fights in juvenile, junior and senior judo players. Rev Paul Educ Fís. 1998;12(1):5-16.

10. Crisafulli A, Vitelli S, Cappai I, Milia R, Tocco F, Melis F, et al. Physiological responses and energy cost during a simulation of a Muay Thai boxing match. Appl Physiol Nutr Metab. 2009;34(2):143-50.

11. Ostrander EA, Huson HJ, Ostrander GK. Genetics of athletic performance. Annu Rev Genomics Hum Genet. 2009;10:407-29.

12. Akhmetov II, Popov DV, Astratenkova IV, Druzhevskaia AM, Missina SS, Vinogradova OL, et al. Using molecular genetic methods for prognosis of aerobic and anaerobic performance in athletes. Fiziol Cheloveka. 2008;34(3):86-91.

13. Yang N, MacArthur DG, Gulbin JP, Hahn AG, Beggs AH, Easteal S, et al. ACTN3 genotype is associated with human elite athletic performance. Am J Hum Genet. 2003;73(3):627-31.

14. Mills $M$, Yang N, Weinberger R, Vander Woude DL, Beggs AH, Easteal S, et al. Differential expression of the actin-binding proteins, alpha-actinin-2 and -3 , in different species: implications for the evolution of functional redundancy. Hum Mol Genet. 2001;10(13):1335-46

15. Jones A, Montgomery HE, Woods DR. Human performance: a role for the ACE genotype? Exerc Sport Sci Rev. 2002;30(4):184-90.

16. Rigat B, Hubert C, Corvol P, Soubrier F. PCR detection of the insertion/deletion polymorphism of the human angiotensin converting enzyme gene (DCP1) (dipeptidyl carboxypeptidase 1). Nucleic Acids Research. 1992;20(6):1433.

17. Shanmugam V, Sell KW, Saha BK. Mistyping ACE heterozygotes. PCR Methods Appl. 1993;3(2):120-1

18. Coelho DB. Determinação da frequência genotípica do ACTN3 e da sua relação com o desempenho físico, respostas hormonais e indicadores do dano muscular em jogadores de futebol [tese]. Belo Horizonte: Universidade Federal de Minas Gerais, Escola de Educação Física, Fisioterapia e Terapia Ocupacional; 2011

19. Kikuchi N, Min SK, Ueda D, Igawa S, Nakazato K. Higher frequency of the ACTN3 R allele + ACE DD genotype in Japanese elite wrestlers. J Strength Cond Res. 2012;26(12):3275-80.

20. Rodríguez-Romo G, Yvert T, de Diego A, Santiago C, Díaz de Durana AL, Carratalá V, et al. No association between ACTN3 R577X polymorphism and elite judo athletic status. Int I Sports Physiol Perform. 2013;8(5):579-81

21. Meira-Lima IV, Pereira AC, Mota GF, Krieger JE, Vallada H. Angiotensinogen and angiotensin converting enzyme gene polymorphisms and the risk of bipolar affective disorder in humans. Neurosci Lett. 2000;293(2):103-6.

22. Cieszczyk P, Maciejewska A, Sawczuk M, Ficek K, Eider J, Jascaniene N. The angiotensin converting enzyme gene I/D polymorphism in ellite polish and lithuanian judo players. Biol Sport. 2010;27(2):119-122.

23. Niemi AK, Majamaa K. Mitochondrial DNA and ACTN3 genotypes in Finnish elite endurance and sprint athletes. Eur J Hum Genet. 2005;13(8):965-9.

24. Norman B, Esbjörnsson M, Rundqvist H, Osterlund T, von Walden F, Tesch PA. Strength, power, fiber types, and mRNA expression in trained men and women with different ACTN3 R577X genotypes. J Appl Physiol (1985). 2009;106(3):959-65.

25. Ahmetov II, Druzhevskaya AM, Lyubaeva EV, Popov DV, Vinogradova OL, Williams AG. The dependence of preferred competitive racing distance on muscle fibre type composition and ACTN3 genotype in speed skaters. Exp Physiol. 2011;96(12):1302-10.

26. Moran CN, Yang N, Bailey ME, Tsiokanos A, Jamurtas A, MacArthur DG, et al. Association analysis of the ACTN3 R577X polymorphism and complex quantitative body composition and performance phenotypes in adolescent Greeks. Eur J Hum Genet. 2007;15(1):88-93.

27. Fiuza-Luces C, Ruiz JR, Rodríguez-Romo G, Santiago C, Gómez-Gallego F, Yvert T, et al. Are 'endurance' alleles 'survival' alleles? Insights from the ACTN3 R577X polymorphism. PLoS One. 2011;6(3):e17558.

28. Pasqua LA, Artioli GG, Oliveira PF, Bertuzzi R. ACtn3 e desempenho esportivo: um gene candidato ao sucesso em provas de curta e longa duração. Rev Bras Cineantropom Desempenho Hum. 2011;13(6):477-83.

29. Ma F, Yang Y, Li X, Zhou F, Gao C, Li M, et al. The association of sport performance with ACE and ACTN3 genetic polymorphisms: a systematic review and meta-analysis. PLoS One. 2013;8(1):e54685.

30. Souza Junior PT, Pereira B. Quantitative and qualitative models of exercise and physical training in sports. Overload, adaptation and adjustment. Braz J Sports Exerc. 2010;1(2):150-7. 